\title{
Regulation of Maize Kernel Carbohydrate Metabolism by Abscisic Acid Applied at the Grain-Filling Stage at Low Soil Water Potential
}

\author{
Zizhu Jiang ${ }^{1,2,+}$, Lin Piao ${ }^{1,+}$, Dong Guo ${ }^{1}$, Hengguang Zhu ${ }^{2}$, Shuai Wang ${ }^{1}$, Hanyu Zhu ${ }^{1}$, Zhanhui Yang ${ }^{1}$, \\ Yuzhao Tao ${ }^{1}$, Ming Li $^{1, *}$ and Changzhuang Liu ${ }^{1}$ \\ 1 College of Agriculture, Northeast Agricultural University, Harbin 150030, China; \\ jiangzizhuneau@163.com (Z.J.); piaolin_007@163.com (L.P.); fredguod@163.com (D.G.); \\ wangshuai960326@163.com (S.W.); zhuhanyu2021@163.com (H.Z.); YZH818GD@163.com (Z.Y.); \\ taoyuzhao111@163.com (Y.T.); liu891578576@163.com (C.L.) \\ 2 Qiqihar Agricultural Technology Extension Center, Qiqihar 161005, China; lianfeng1011@163.com \\ * Correspondence: liming@neau.edu.cn \\ + These authors contributed equally to this work.
}

check for

updates

Citation: Jiang, Z.; Piao, L.; Guo, D.; Zhu, H.; Wang, S.; Zhu, H.; Yang, Z.; Tao, Y.; Li, M.; Liu, C. Regulation of Maize Kernel Carbohydrate

Metabolism by Abscisic Acid Applied at the Grain-Filling Stage at Low Soil Water Potential. Sustainability 2021,

13, 3125. https://doi.org/

10.3390/su13063125

Academic Editor: Stefania De Pascale

Received: 4 February 2021

Accepted: 5 March 2021

Published: 12 March 2021

Publisher's Note: MDPI stays neutral with regard to jurisdictional claims in published maps and institutional affiliations.

Copyright: (c) 2021 by the authors. Licensee MDPI, Basel, Switzerland. This article is an open access article distributed under the terms and conditions of the Creative Commons Attribution (CC BY) license (https:/ / creativecommons.org/licenses/by/ $4.0 /)$.

\begin{abstract}
A water deficit during the grain-filling stage increases the frequency of yield loss in maize (Zea mays L.). Abscisic acid (ABA) plays a regulatory role in many stages of plant growth; however, its effects on sucrose-metabolizing enzyme activities under stress are poorly understood. The activities of cell-wall-bound acid invertase, vacuolar invertase, cytoplasmic invertase, and sucrose synthase decreased continuously under drought stress, whereas ABA treatment partially restored these activities. In addition, the increase and development of sucrose content under drought stress were related to invertase activity. Up-regulation of the activities and gene expression of cell-wallbound acid invertase and vacuolar invertase with ABA treatment contributed to the increase in the number of rows and number of grains per row. Furthermore, ABA inhibited the increase in the length of the bald tip. Compared with the control group, water stress significantly reduced the yield index, with the lowest yield index on the 10th day of stress. These results suggest that the increase in ABA-induced sucrose-metabolizing enzyme activity might be an effective mechanism to improve maize drought resistance at the grain-filling stage.
\end{abstract}

Keywords: maize; water stress; abscisic acid; carbon assimilation; invertase; gene expression; yield

\section{Introduction}

Maize is widely planted all over the world, with an annual output of approximately 1 billion tons [1]. The life cycle of maize is 80-110 days, and the plant requires more water (500-800 $\mathrm{mm}$ ) than other crops during growth. However, maize is primarily grown in North and South America, Northeast China, and other parts of Asia, Africa, and Europe; all of which are susceptible to drought [2]. The filling stage is considered a crucial period of maize growth and development and is particularly sensitive to water stress. Indeed, water is the key factor limiting corn production. In the mainspring production areas of China, a loss of $50 \%$ corn yield will be caused by the lack of sufficient water [3], and the maximum yield loss due to water deficit is $20 \%$, during the filling period [4]. The effect of varying degrees of drought stress on maize is ultimately attributed to the loss of grain yield.

Studies on a large number of plant species have revealed that sucrose (Suc) is the final product of photosynthesis [5,6]. Carbohydrates originating from Suc constitute nearly $90 \%$ of the plant biomass [7]. Suc is metabolized into hexose (Hex) by invertase through phloem unloading, resulting in a swelling pressure difference by osmosis [8]. The mass flow of water is driven by this difference in turgor, which brings assimilates from source to sink, tissues to power, and supports the growth of the latter [9]. Almost all (60-98.2\%) carbon in the process of grain filling comes from this Suc breakdown $[10,11]$. Therefore, sucrose 
unloading is a crucial yield determinant [12]. In terms of grain development, before anthesis drought affects the differentiation and development of florets; whereas, after anthesis, the duration of grain filling is shortened, the filling of weak grain is insufficient (bald tip is increased), and the number of abortive grains is increased [4]. In-depth studies of corn yield formation have confirmed that corn grain yield mainly depends on the accumulation of dry matter after anthesis (especially the dry matter partitioned to the grain); therefore, sucrose transport has become a new research hotspot of high-yield physiology in corn $[13,14]$.

Suc is translocated to sinks through the phloem and metabolized into Hex or its derivatives, either by invertases (INVs) or by Suc synthase (SS), and then used in different ways [15]. Suc is hydrolyzed into glucose (Glc) and fructose (Fru) by INVs, while it is hydrolyzed into UDP-Glc and Fru by SS in the presence of UDP [16]. INVs are classified as apoplastic (cell wall), vacuolar, or cytoplasmic isoforms based on their optimum $\mathrm{pH}$ and subcellular locations [17]. These forms are referred to as cell wall invertases (CWIN), vacuolar invertase (VIN), and cytoplasmic invertase (CIN). SS is another Suc degrading enzyme occurring in plants besides INVs. Suc has been used as a biochemical marker of sink strength [18-20]. According to a compelling body of evidence in diverse crop species, SS is considered to have an important effect on sink development [21].

Abscisic acid is a plant endogenous hormone that plays an important role in plant responses to abiotic stress conditions, such as water deficit, high salt, and high temperature [22]. In recent years, the ABA-induced enhancement of drought resistance has become a research hotspot $[23,24]$. Previous studies on ABA mitigation of drought stress effects mainly focused on sugarcane [25,26], cotton [27], soybean [28], wheat [29,30], and maize [31], among other crop species. ABA can maintain normal physiological and metabolic functions, such as sugar metabolism and enzyme activity, in flowering soybean under drought stress [28]. In this case, exogenous ABA treatment increased carbohydrate accumulation and translocation to grains at the flowering stage and increased the yield of dryland wheat [22]. However, there are few reports on the physiological mechanism underlying ABA-mediated mitigation of drought stress effects at the grain-filling stage in maize. In this study, the maize cultivar Zhengdan 958 was used as experimental material. Water stress and ABA foliar spraying pretreatment were applied at the grain-filling stage. We investigated the effects of ABA on the yield index and the sucrose, glucose, and fructose content, the activity of sucrose synthase and invertases, and the gene expression of invertases under drought stress. The regulation of ABA on carbon metabolism in maize was studied under water stress to provide a theoretical basis and technical support for drought-resistant cultivation of maize.

\section{Materials and Methods}

\subsection{Plant Material, Growth Conditions, Experimental Design, and Sampling}

The experiment was carried out in the drought shed at the test base of Northeast Agricultural University in Harbin, China. ABA was obtained from China Harbin Chemical Company, Ltd. The agricultural means company from China Henan provided the maize inbred line Zhengdan 958.

All treatments were placed in the dry shed during the entire growth period. The top diameter of the experimental plastic pots was $27.5 \mathrm{~cm}$, the bottom diameter was $20 \mathrm{~cm}$, and the pot height was $25 \mathrm{~cm}$. Several holes were punched at the bottom to facilitate drainage. Each pot was filled with $12.5 \mathrm{~kg}$ of soil. The soil used in the experiment was black soil for which basic fertility was analytically determined: total nitrogen $\left(1.43 \mathrm{~g} \cdot \mathrm{kg}^{-1}\right)$, available potassium (254.55 $\left.\mathrm{mg} \cdot \mathrm{kg}^{-1}\right)$, available phosphorus $\left(33.93 \mathrm{mg} \cdot \mathrm{kg}^{-1}\right)$, organic matter $\left(4.86 \mathrm{~g} \cdot \mathrm{kg}^{-1}\right)$, alkali hydrolyzed nitrogen $\left(186.17 \mathrm{mg} \cdot \mathrm{kg}^{-1}\right), \mathrm{pH}$ 6.85. For each basin, all potted plants were arranged in the same plot (excluding the interference of climatic factors), soil testing, and fertilization (according to the unified amount of fertilization standard, excluding the interference of soil nutrient factors), and implementation of weed and pest control was standardized. 
After sowing, the growth period was recorded, the same growing plants were selected from the male, and bagged pollination was conducted at silking (the pollination time in the treatment room depended on the test situation).

Maize plants at the filling stage were treated with one of the following four treatments: (1) CK, untreated; (2) drought stress (for 4, 7, or 10 days); (3) ABA, foliar spraying ABA $0.5 \mathrm{mmol} \mathrm{L}{ }^{-1}$ under non-stress conditions; (4) water stress + ABA, foliar spraying ABA $0.5 \mathrm{mmol} \mathrm{L}^{-1}$ under water stress. The ABA dose $\left(0.5 \mathrm{mmol} \mathrm{L}^{-1}\right)$ was selected based on previous experiments. The previous experiment was to screen the concentration of ABA, and the results showed that $0.5 \mathrm{mmol} \mathrm{L}^{-1} \mathrm{ABA}$ had the strongest regulatory effect on drought stress. This experiment was repeated five times.

The amount of irrigation water used in the normal water supply treatment and rehydration treatment was $80 \mathrm{~mm}$ (soil relative water content $=75-80 \%$ ); the irrigation amount was controlled by a water meter. A Swp-100 portable soil water potential tester (Nanjing Soil Research Institute, Chinese Academy of Sciences) was used for real-time monitoring of soil water potential (the probe was buried at approximately $15 \mathrm{~cm} \mathrm{depth),}$ and three fixed-point measurements were made for each treatment. Soil water potential was recorded over $24 \mathrm{~h}$ on the day of treatment, and the readings of the soil water potential tester were collected from 10:30-11:30 every day. When the soil water potential was lower than the set value, supplementary irrigation was used to restore the preset water potential and the amount of irrigation water applied was recorded.

After treatment, samples (ears) were collected every three days and frozen in liquid nitrogen $\left(-80^{\circ} \mathrm{C}\right)$; middle grains from the corn ears were sampled to determine sucrose content and enzyme activities.

\subsection{Measurements of Sucrose, Glucose, and Fructose Content}

Next, $0.5-1.0 \mathrm{~g}$ of the mixed grain sample was weighed. It was put into a large test tube. Afterward, $15 \mathrm{~mL}$ of distilled water was added and it was filtered into a $100 \mathrm{~mL}$ volumetric flask. Then the volume was fixed to the scale, making the solution to be tested.

According to the resorcinol method of Marx et al. [32], $0.2 \mathrm{~mL} \mathrm{80 \%} \mathrm{ethanol} \mathrm{extract,}$ $200 \mu \mathrm{L} 2 \mathrm{~mol} \mathrm{~L}^{-1} \mathrm{NaOH}$ was added and mixed thoroughly; then placed in a boiling water bath for $10 \mathrm{~min}$ to decompose fructose, glucose, and other reducing sugars. Then, $2 \mathrm{~mL}$ of $30 \% \mathrm{HCl}$ was added, mixed well, maintained at $80^{\circ} \mathrm{C}$ for $10 \mathrm{~min}, 1 \mathrm{~mL}$ of $1 \%$ resorcinol was added, kept at $80{ }^{\circ} \mathrm{C}$ for $10 \mathrm{~min}$, allowed to cool down, and absorbance was determined at $480 \mathrm{~nm}$.

A total of $0.5 \mathrm{ml} 0.01 \mathrm{~mol} \mathrm{~L}^{-1} \mathrm{AgNO}_{3}, 0.75 \mathrm{~mL} 0.1 \mathrm{~mol} \mathrm{~L}-1 \mathrm{NaOH}$ was added in turn and mixed thoroughly, placed in a boiling water bath for $10 \mathrm{~min}$, and then cool to room temperature. Next, $0.75 \mathrm{~mL} 0.004$ molL $^{-1}$ ammonium ferric sulfate solution, $2.5 \mathrm{~mL}$ buffer solution, and $1.5 \mathrm{~mL} 0.1 \%$ ophenanthroline solution were added in turn, placed in boiling water bath for $20 \mathrm{~min}$, allowed to cool down, and absorbance was determined at $510 \mathrm{~nm}[33]$.

Three $\mathrm{mL}$ concentrated hydrochloric acid was added, fixed the volume to $10 \mathrm{~mL}$ with distilled water, placed in boiling water bath for $8 \mathrm{~min}$. It was cooled down rapidly with running water, and absorbance was determined at $285 \mathrm{~nm}$ [34].

\subsection{Measurement of Sucrose Synthetase Activity}

The method of enzyme extraction was as described by Douglas et al. [35] and Tsai-Mei and Lloyd [36]. Briefly, $1 \mathrm{~g}$ of leaf tissue was weighed and added with $10 \mathrm{~mL}$ HEPES NaOH buffer solution ( $\mathrm{pH} 7.5)$, ground in an ice bath, then freeze centrifuged at $10000 \times g$ for $10 \mathrm{~min}$, at $4{ }^{\circ} \mathrm{C}$. The supernatant was used as an enzyme extract solution. The determination of SS activity was performed according to Douglas et al. [35] and Tsai-Mei and Lloyd [36] using the following steps: (1) determination of sucrose content before reaction: as described above. (2) Determination of sucrose content after reaction: $50 \mu \mathrm{L}$ enzyme solution was added to $50 \mu \mathrm{L}$ of HEPES NaOH buffer solution (pH 7.5), $20 \mu \mathrm{L} 50 \mathrm{mmol} / \mathrm{L} \mathrm{MgCl} 2,20 \mu \mathrm{L}$ $100 \mathrm{mmol} / \mathrm{L}$ uridine diphosphate glucose (UDPG), and $20 \mu \mathrm{L} 100 \mathrm{mmol} / \mathrm{L}$ fructose. After 
$30 \mathrm{~min}$ in a water bath at $30{ }^{\circ} \mathrm{C}, 200 \mu \mathrm{L} 2 \mathrm{~mol} / \mathrm{L} \mathrm{NaOH}$ was added, and the reaction was terminated by boiling in water for $10 \mathrm{~min}$. Then, $1.5 \mathrm{~mL} \mathrm{30 \%} \mathrm{HCl}$ and $0.5 \mathrm{~mL} 1 \%$ resorcinol were added, shaken thoroughly, and placed in a constant temperature water bath at $80{ }^{\circ} \mathrm{C}$ for $10 \mathrm{~min}$. After cooling, absorbance was determined at $480 \mathrm{~nm}$ and the sucrose content was calculated from a sucrose standard curve. The difference between (2) and (1) is the content of sucrose generated by the reaction, and SS activity is expressed by the sucrose content per minute per unit of fresh weight of plant material [37].

\subsection{Measurement of Sucrose Invertase Activity}

Sucrose invertase activity was measured according to Ranwala et al. [17], after slight modifications. A total of $0.4 \mathrm{~g}$ of fresh grain was weighed, $4 \mathrm{~mL} 50 \mathrm{mmol} \mathrm{L}^{-1} \mathrm{Hepe}-\mathrm{NaOH}$ (PH7.5) was added, ground into homogenate, centrifuged at $4{ }^{\circ} \mathrm{C}$, and the supernatant was used to determine VIN and CIN. The precipitate was washed with $3 \mathrm{~mL} 50 \mathrm{mmol} \mathrm{L}^{-1}$ Hepe $-\mathrm{NaOH}$ (PH7.5) and then added with $1 \mathrm{~mL} 500 \mathrm{mmol} \mathrm{L}^{-1} \mathrm{NaCl}$. It was left to stand at $4{ }^{\circ} \mathrm{C}$ for one night. Centrifugation was performed at $4{ }^{\circ} \mathrm{C}$ and the supernatant was used to determine the activity of CWIN.

The reaction mixture was $0.3 \mathrm{~mL}$ of $100 \mathrm{mmol} \mathrm{L}^{-1} \mathrm{CH} 3 \mathrm{COONa}, 0.1 \mathrm{~mL}$ of $100 \mathrm{mmol} \mathrm{L}^{-1}$ sucrose solution, and $0.1 \mathrm{~mL}$ of supernatant enzyme extract. The reaction was carried out at $30{ }^{\circ} \mathrm{C}$ for $15 \mathrm{~min}$, and then $0.5 \mathrm{~mL}$ of 3,5-Dinitrosalicylic acid (DNS) reagent was added to the mixture solution in a boiling water bath for $5 \mathrm{~min}$. After cooling, the absorbance of the DNS reagent was determined at $540 \mathrm{~nm}$. DNS is difficult to dissolve, so it was wrapped in a black plastic bag to prevent light separation. After fully dissolving, the volume was fixed to $1 \mathrm{~L}$ and put in a brown bottle. It can be used after 10 days. The content of reducing sugar was determined by an enzyme-linked immunosorbent assay (sodium acetate was replaced by sodium phosphate when CIN activity was determined, other reagents remained unchanged). The reaction without substrate was used as the control. The enzyme activity is expressed as the amount of reducing sugar produced by the enzyme contained in one protein unit per unit of time.

\subsection{Measurement of Yield Index}

Corn grain yield was calculated at $14 \%$ moisture content. According to the average ear weight and the ratio of large and small panicles, 10 ears were selected for the indoor test, and the bald tip, row number, and grain number per row were determined. Then, the grains were dried at $80{ }^{\circ} \mathrm{C}$ to a constant weight, and the 1000-grain weight was measured.

\subsection{RNA Isolation and Real-Time RT-PCR}

Total RNA was isolated from maize kernels using TRIzol reagent (Invitrogen, Carlsbad, CA, USA). Specific primers for each gene were designed from the $3^{\prime}$ ends of the gene sequences by Primer Premier 5.0 (Table 1). The TM value should be between and $55-60{ }^{\circ} \mathrm{C}$. The cDNA sample was diluted five times as a template for computer detection. The reagent used for real-time quantitative PCR was 2X SG Fast qPCR Master Mix (B639271, BBI) and the instrument was the LightCycler480 II (Roche Molecular Systems Inc. Pleasanton, CA, USA) [38]. Relative quantification was used to get the expression difference between the CT value of the internal reference gene and the CT value of the gene to be detected through $2^{-\Delta \Delta C t}$ mathematical operation. The $2^{-\Delta \Delta C t}$ method was used to calculate the relative transcript levels, with Glyceraldehyde-3-phosphate dehydrogenase (GAPDH) as the housekeeping gene [39]. Technical support was provided by bio engineering Co., Ltd. in Shanghai.

\subsection{Statistical Analysis}

Experimental data are shown as means \pm SD. Statistical analyses were performed using Microsoft Excel 2007 and SPSS 17 software. Treatment means were compared using Fisher's LSD test at a significance level of $p<0.05$. 
Table 1. Primer sequences for real-time RT.

\begin{tabular}{|c|c|c|}
\hline Gene & Forward Sequence & Reverse Sequence \\
\hline GAPDH & 5'-CССТTCATCACCACGGACTA-3' & 5'-CTCACCCCACGGGATTTC-3' \\
\hline IVR1 & 5'-GACGGCAGCCTCCAAACT-3' & 5'-TTCTCСССАTCTAGCACAGG-3' \\
\hline IVR2 & 5'-ATGGGTTGGCGAGACAGAC-3' & $5^{\prime}$-GATGGTGATGCCGCTGAG-3' \\
\hline Incw1 & X TCCAGCCGCCAATGAACT & x ACCAGCAGCCGTACTTGT \\
\hline Incw2 2 & $5^{\prime}$-CGGGATACAAACGGCACA- $3^{\prime}$ & $5^{\prime}$-GCTTGAACACCCTGAAGAACA- $3^{\prime}$ \\
\hline Incw3 & 5'-CCTCATGTGCAACGACCCTA-3' & 5'-CGTGGTTGAAGACGAAGAGGT-3' \\
\hline Incw4 & 5'-ACACCGCTGTCTTCTTCCG-3' & $5^{\prime}$-GATGGTCTCGTGCTCCTCAA- $3^{\prime}$ \\
\hline
\end{tabular}

\section{Results}

\subsection{Sucrose, Glucose, and Fructose Content of Ovaries}

The dynamic changes in sucrose content during grain filling are shown in Table 2 and Figure 1. The different drought treatments had different effects on the sugar content of the ovary (Figure 1A). The sugar content under drought stress was higher than that of the control, and the highest increase was found on the 10th day, reaching $63.18 \%$. In plants with an unlimited water supply, the concentration of Suc in the ovaries decreased (Figure 1A). The controls differed from and drought-treated plants on the 4th day and then changed more with severe stress. These differences may be consistent with differences in utilization efficiency of Suc. A similar pattern was observed under high temperature on sucrose content in rice during grain filling. On the 4th and 7th days of drought stress, the sucrose content of ABA-treated plants was significantly lower than that of ABA-untreated plants.

Table 2. Fvalues from analysis of variance (ANOVA) of the data for Suc, Glu, and Fru content, sucrose synthase (SS), vacuolar invertase (VIN), cytoplasmic invertase (CIN), and cell wall invertases (CWIN) activity of Zhengdan958 under three treatments (CK stress, stress + ABA) and four stress dates $(0,4$ th, 7 th, 10 th $)$.

\begin{tabular}{ccccccccc}
\hline Source of Variation & df & $\begin{array}{c}\text { Suc } \\
\text { Content }\end{array}$ & $\begin{array}{c}\text { Glu } \\
\text { Content }\end{array}$ & $\begin{array}{c}\text { Fru } \\
\text { Content }\end{array}$ & $\begin{array}{c}\text { SS } \\
\text { Activity }\end{array}$ & $\begin{array}{c}\text { VIN } \\
\text { Activity }\end{array}$ & $\begin{array}{c}\text { CIN } \\
\text { Activity }\end{array}$ & $\begin{array}{c}\text { CWIN } \\
\text { Activity }\end{array}$ \\
\hline $\mathrm{T}$ & 2 & $116.061^{* * *}$ & $425.243^{* * *}$ & $386.947^{* * *}$ & $637.950^{* * *}$ & $1606.622^{* * *}$ & $1531.118^{* * *}$ & $1089.682^{* * *}$ \\
$\mathrm{~S}$ & 3 & $9^{* 480^{* * *}}$ & $21.461^{* * *}$ & $80.236^{* * *}$ & $614.557^{* * *}$ & $322.431^{* * *}$ & $165.650^{* * *}$ & $432.196^{* * *}$ \\
$\mathrm{~T} \times \mathrm{S}$ & 6 & $31.659^{* * *}$ & $100.743^{* * *}$ & $125.635^{* * *}$ & $359.418^{* * *}$ & $287.110^{* * *}$ & $264.002^{* * *}$ & $194.042^{* * *}$ \\
\hline
\end{tabular}

T: treatment; $S$ : stress, ${ }^{* * *}$ significant at 0.001 probability.

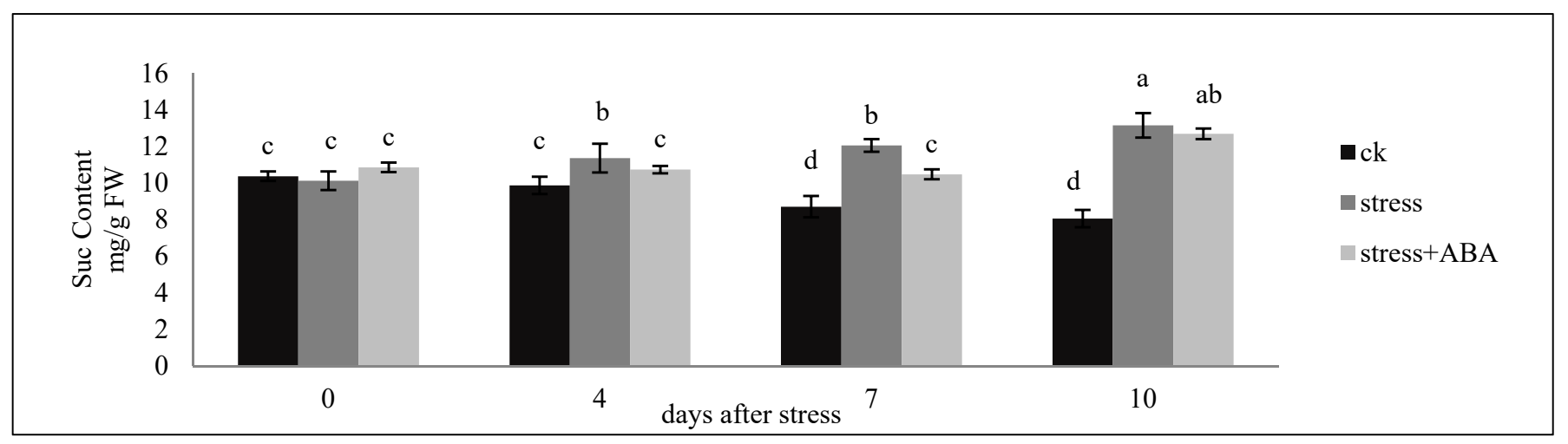

(A)

Figure 1. Cont. 


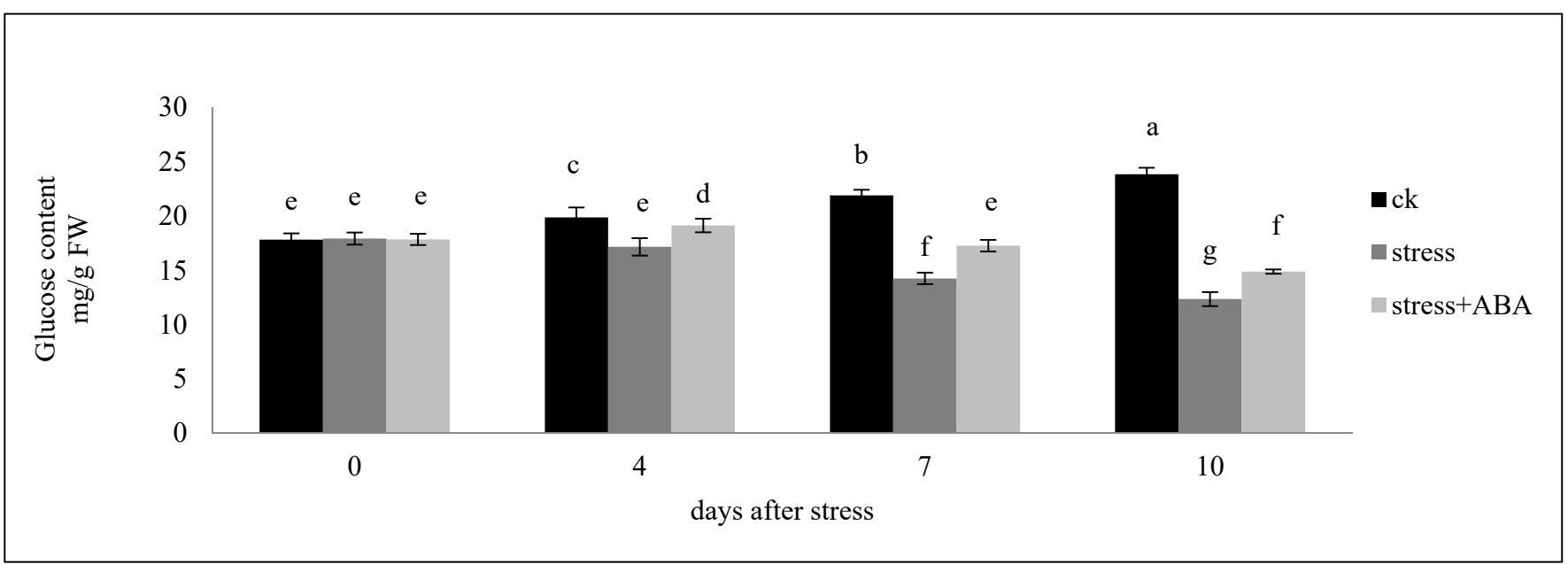

(B)

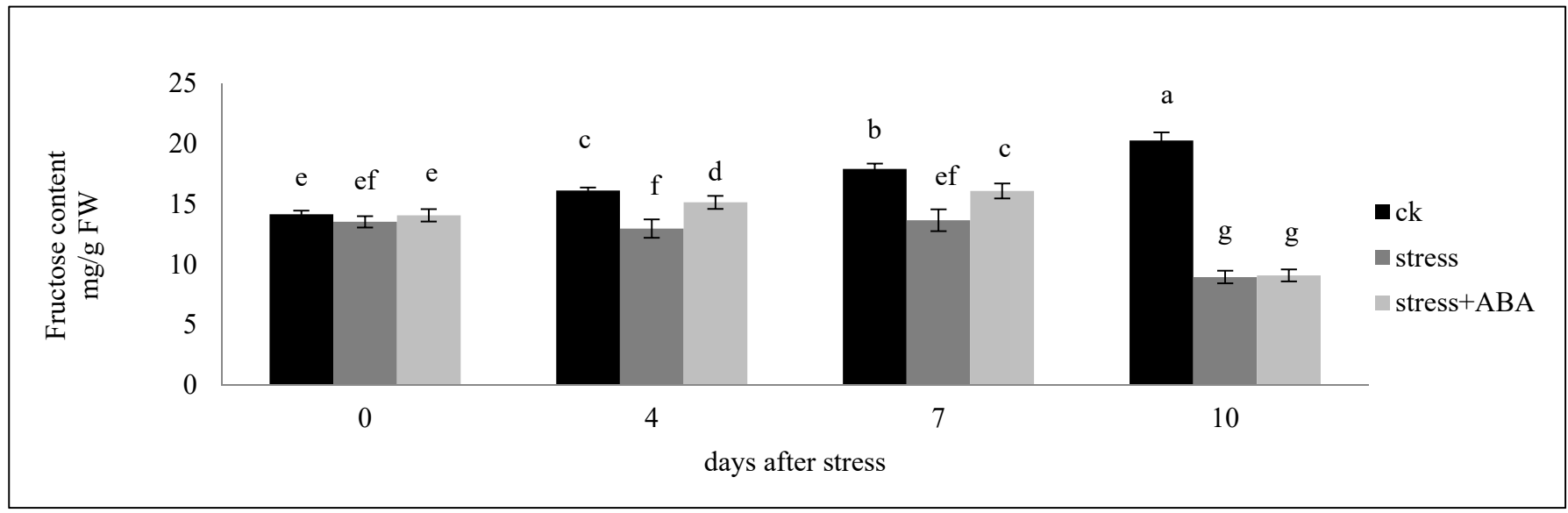

(C)

Figure 1. Effects of exogenous abscisic acid (ABA) application on the Suc content (A), Glu content (B), Fru content (C) in ovaries of maize kernels exposed to drought stress for 10 days. The data represent the means of independent measurements for five replicates. Standard deviation is indicated by vertical error bars. Values with the same lowercase letters on the bars are not significantly different at $p<0.05$.

The glucose content of control grains increased with time after pollination and reached a maximum value 10 days after pollination. Grain glucose and fructose contents significantly decreased under drought stress. On the 4 th, 7 th, and 10th days after treatment initiation, glucose content decreased by $13.65 \%, 34.95 \%$, and $48.25 \%$, respectively, compared with the control; decreasing the most on the 10th day. Conversely, exogenous application of ABA significantly increased the glucose content but on the $4 \mathrm{th}, 7 \mathrm{th}$, and 10th days, the glucose content decreased by $3.72 \%, 21.14 \%$, and $37.61 \%$, respectively, compared with the control. The remission effect of ABA was strongest on the 4th day but then gradually weakened. The changing trend of fructose content was similar to that of glucose. The effect of ABA on fructose content was greater on the 4th day than on the 7th day. Finally, on the 10th day, ABA had little effect on fructose content, which was the same as that under drought stress by itself.

\subsection{Effects of Drought Stress and/or ABA Application on Sucrose Synthase Activity}

The changes in sucrose synthase activity during grain filling are shown in Table 2 and Figure 2. On the 4 th day, the activity of sucrose synthase was significantly higher in plants under drought stress than among control plants. On the 7th and 10th days, SS activity declined under drought stress. Thus, the ability for sucrose decomposition through the 
sucrose synthase pathway showed a downward trend. Compared with that of the control, SS activity decreased by $59.45 \%$ and $84.96 \%$ in response to drought stress treatment and by $16.28 \%$ and $68.18 \%$ in response to drought + ABA treatment, respectively. Exogenous ABA partially alleviated this inhibition, and the remission effect observed on the 7 th day was greater than that on the 10 th day.

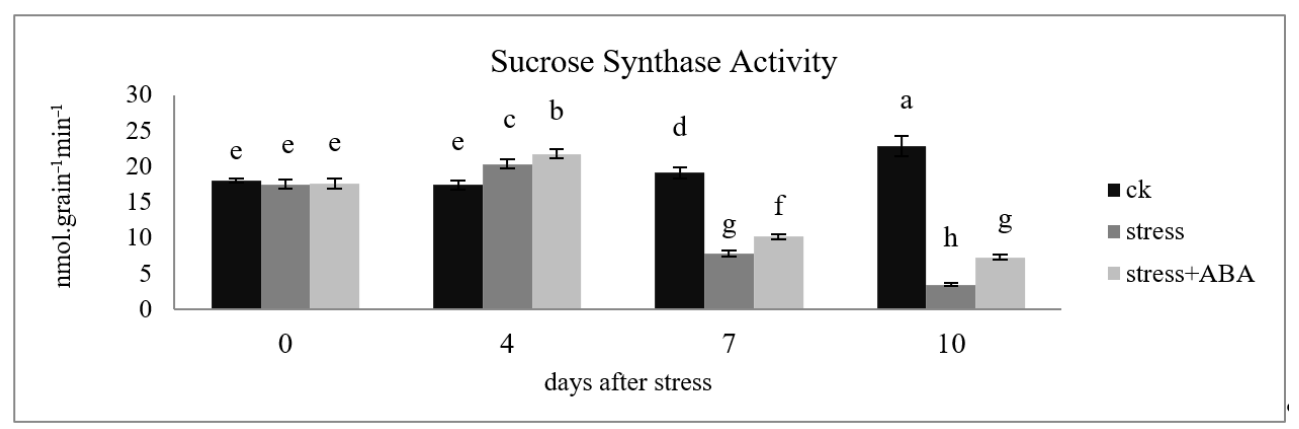

Figure 2. Effects of exogenous ABA application on the sucrose synthase activity in ovaries of maize kernels exposed to drought stress for 10 days. The data represent the means of independent measurements for five replicates. Standard deviation is indicated by vertical error bars. Values with the same lowercase letters on the bars are not significantly different at $p<0.05$.

\subsection{Effects of Drought Stress and/or ABA Application on Vacuolar Invertase Activity}

There was no significant change in vacuolar invertase activity of control plants on the 4th day, but then VIN increased (Figure 3), reaching the highest level on the 10th day. The activity of VIN in plants pretreated with ABA was higher than that in plants treated with drought stress alone. There were significant differences in VIN activity between drought stress and drought stress + ABA treatment from the 1st day to the 10th day (Table 2). On the 4 th, 7 th, and 10th days, VIN activity decreased by $28.93 \% 44.77 \%$, and $57.60 \%$, respectively, under the drought stress + ABA treatment; further it decreased by $16.91 \%$, $27.31 \%$, and $41.94 \%$, respectively, relative to control values. With continuous drought stress, VIN activity decreased gradually. However, ABA application attenuated the decrease in VIN activity.

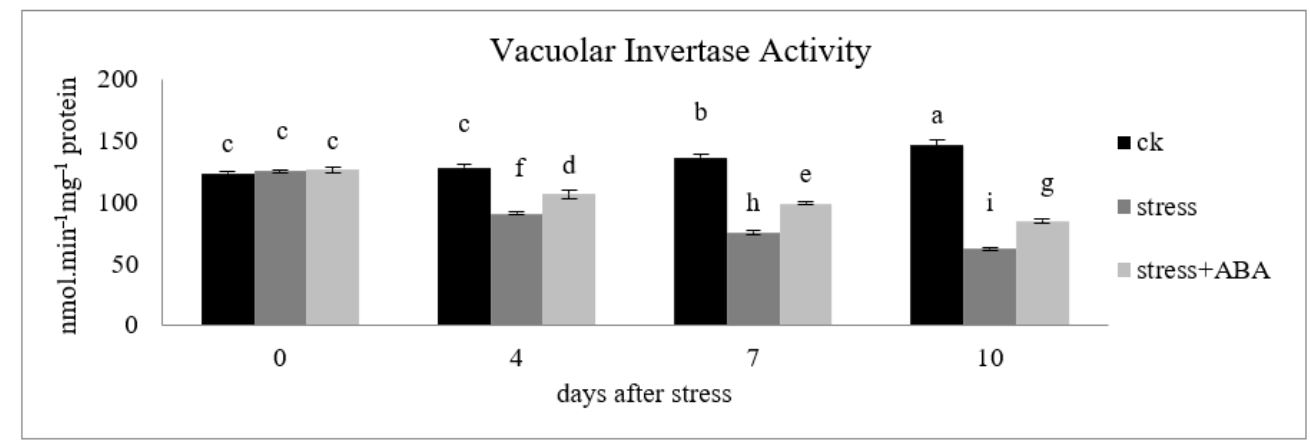

Figure 3. Effects of exogenous ABA application on vacuolar invertase activity in ovaries of maize kernels exposed to drought stress for 10 days. The data represent the means of independent measurements for five replicates. Standard deviation is indicated by vertical error bars. Values with the same lowercase letters on the bars are not significantly different at $p<0.05$.

\subsection{Effects of Drought Stress and/or ABA Application on Cell Wall Invertase Activity}

Cell wall invertase activity (CWIN) of untreated plants decreased first and then increased in Figure 4. On the 10th day, the CWIN activity of the control plants was the highest. The activity of CWIN decreased by $28.16 \%, 38.86 \%$, and $51.51 \%$, respectively, on the 4 th, 7 th, and 10th days of drought treatment. The activity of CWIN decreased significantly under drought stress, and with the extension of stress time, the activity of CWIN decreased 
further. On the 4th, 7th, and 10th days, drought + ABA treatment decreased by $7.62 \%$, $20.69 \%$, and $35.37 \%$, respectively, compared with controls. With the severity of stress, the alleviating and inhibiting effects of ABA decreased, and the effect was strongest in the early stage of stress.

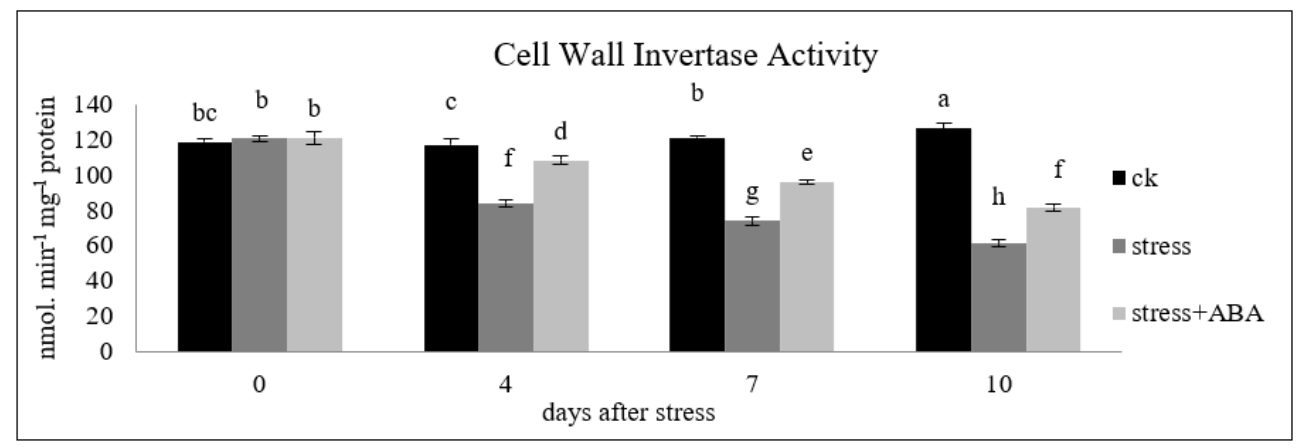

Figure 4. Effects of exogenous ABA application on cell wall invertase activity in ovaries of maize kernels exposed to drought stress for 10 days. The data represent the means of independent measurements for five replicates. Standard deviation is indicated by vertical error bars. Values with the same lowercase letters on the bars are not significantly different at $p<0.05$.

\subsection{Effects of Drought Stress and/or ABA Application on Cytoplasmic Invertase Activity}

Cytoplasmic invertase activity (CIN) activity of untreated plants showed an upward trend in Figure 5. On the 10th day, CIN activity was the highest. The activity of CIN decreased by $48.38 \%, 65.74 \%$, and $83.06 \%$, respectively, on the 4 th, 7 th, and 10 th days of drought treatment. CIN activity decreased significantly under drought stress, and with the extension of stress time, the activity decreased further. On the 4 th, 7 th, and 10th days, drought + ABA treatment decreased by $21.91 \%, 43.93 \%$, and $62.74 \%$, respectively, compared with controls. With the severity of stress, the alleviating and inhibiting effects of ABA decreased, and the effect was strongest in the early stage of stress.

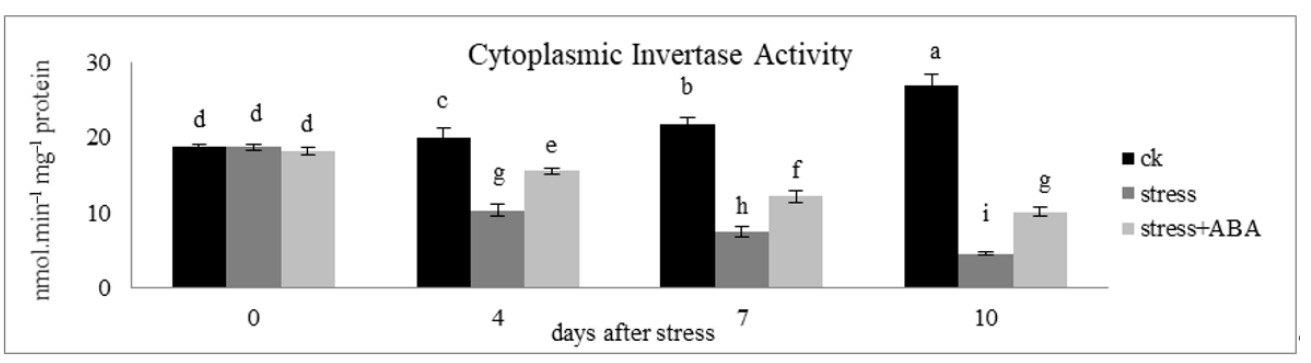

Figure 5. Effects of exogenous ABA application on the cytoplasmic invertase activity in ovaries of maize kernels exposed to drought stress for 10 days. The data represent the means of independent measurements for five replicates. Standard deviation is indicated by vertical error bars. Values with the same lowercase letters on the bars are not significantly different at $p<0.05$.

\subsection{Effects of Drought Stress and/or ABA Application on the Expression of Genes Encoding Invertase Enzymes}

Drought-induced changes in VIN activity (Figure 3) were also evident at the mRNA level (Figure 6A,B). This is consistent with previous studies that have shown that the mRNA level of Ivr2 is significantly higher than that of IVR1 in young ovaries. With the severity of stress, this was obvious in different treatments (Figure 6A,B). The relative levels of IVR1 and Ivr2 mRNAs (Figure 6A,B) were significantly lower under drought stress compared with well-watered controls. Although mean relative IVR1 mRNA, IVR2 mRNA levels under drought stress $+\mathrm{ABA}$ (Figure 6A,B) tended to be higher, there was no significant difference between these and those observed under drought stress alone on the 4th day. 


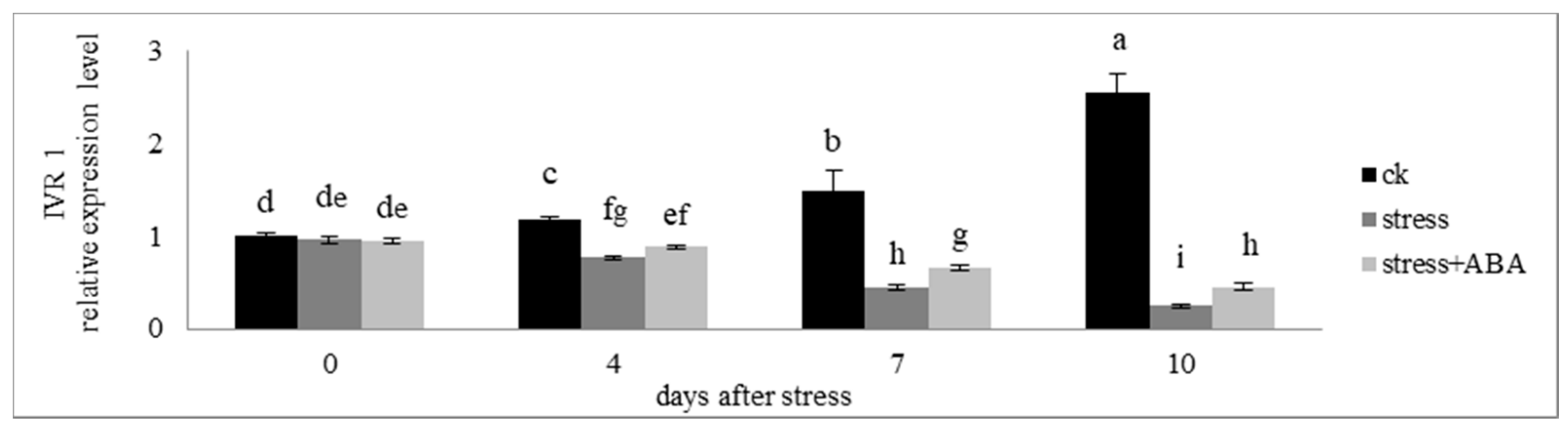

(A)

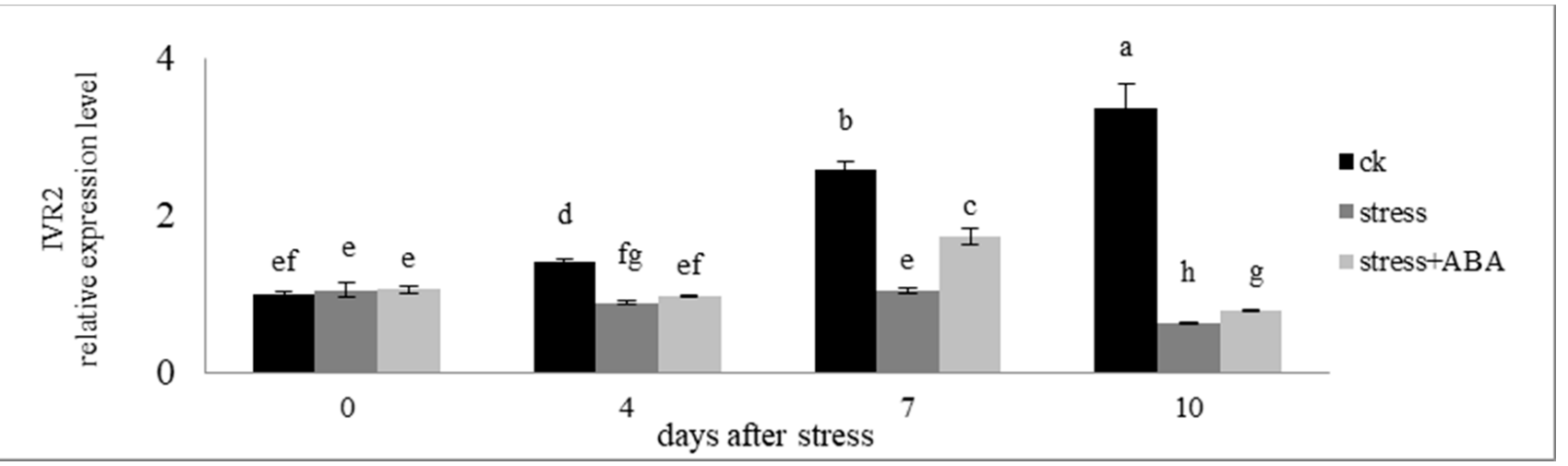

(B)

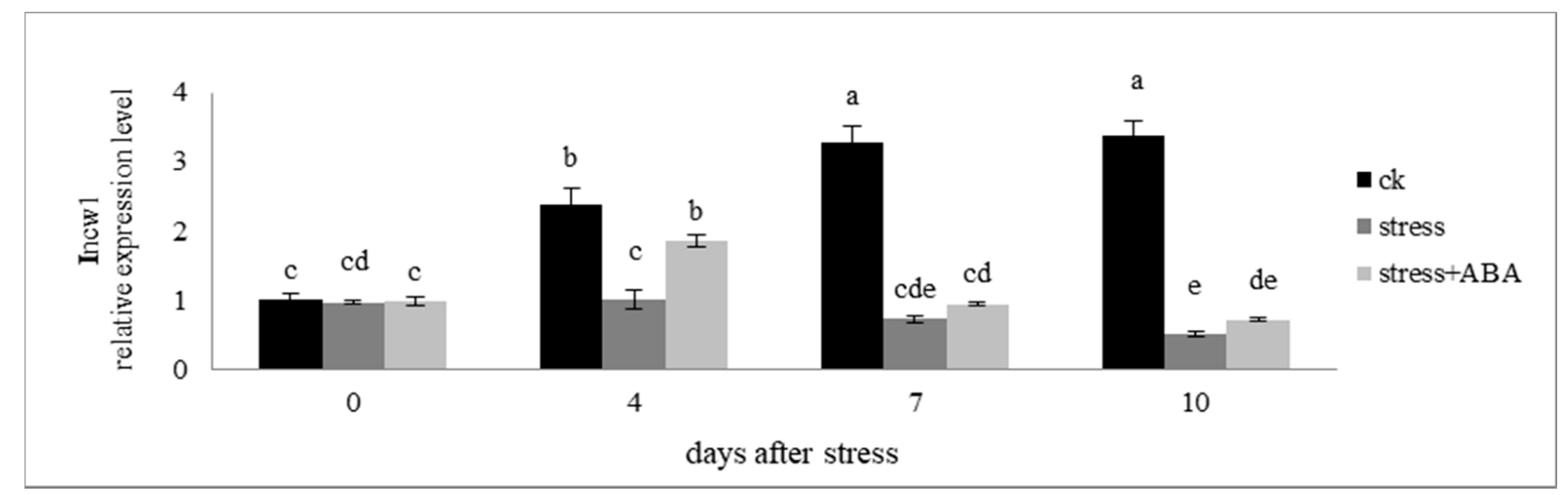

(C)

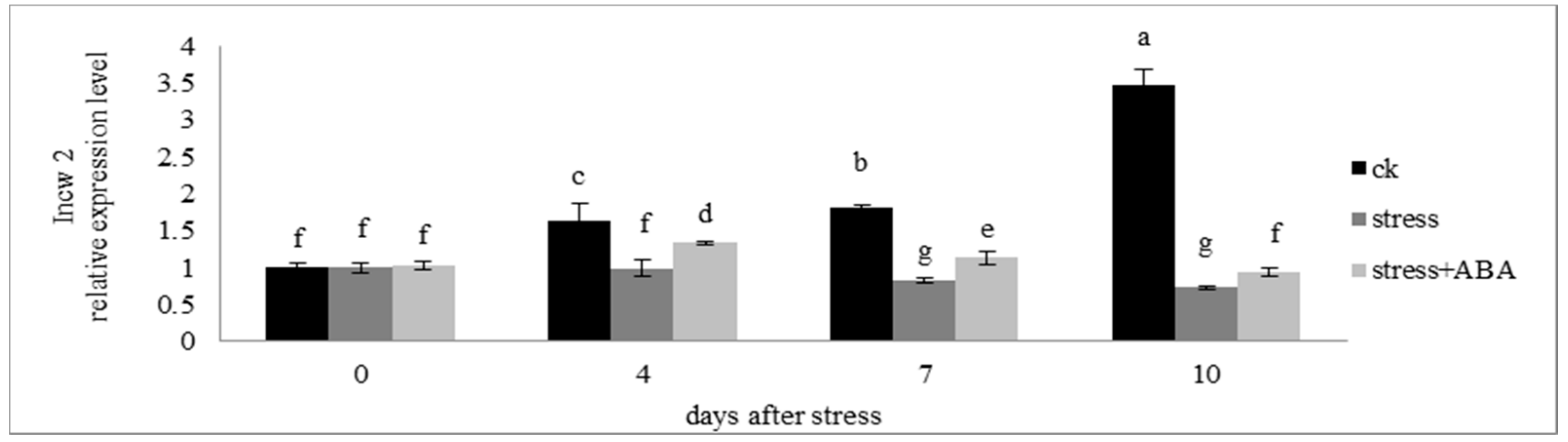

(D)

Figure 6. Cont. 


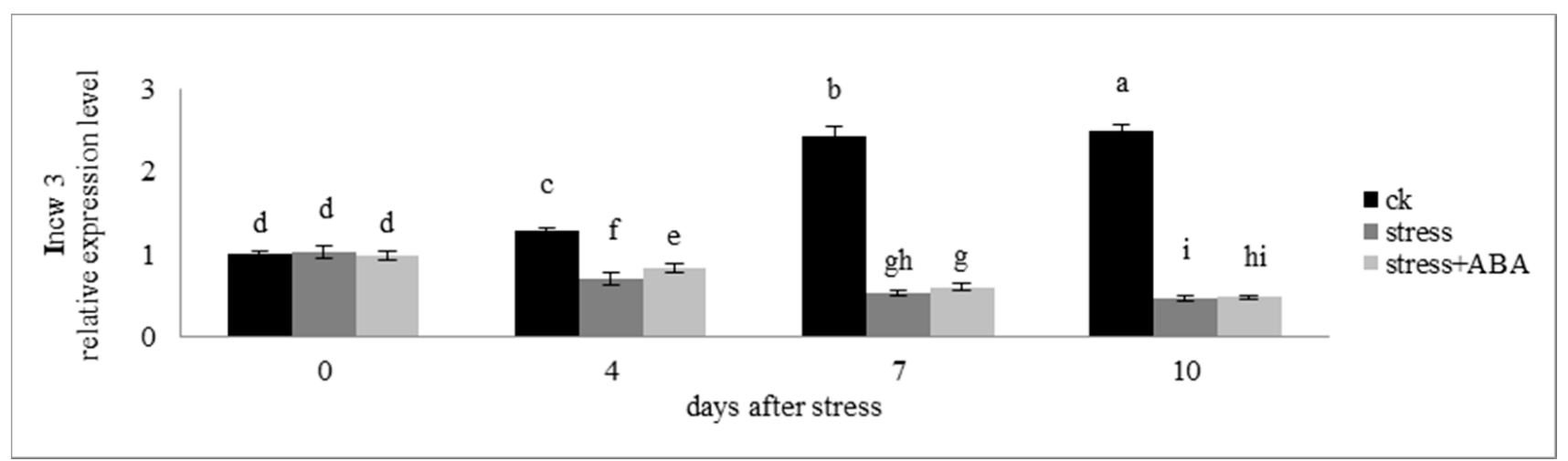

(E)

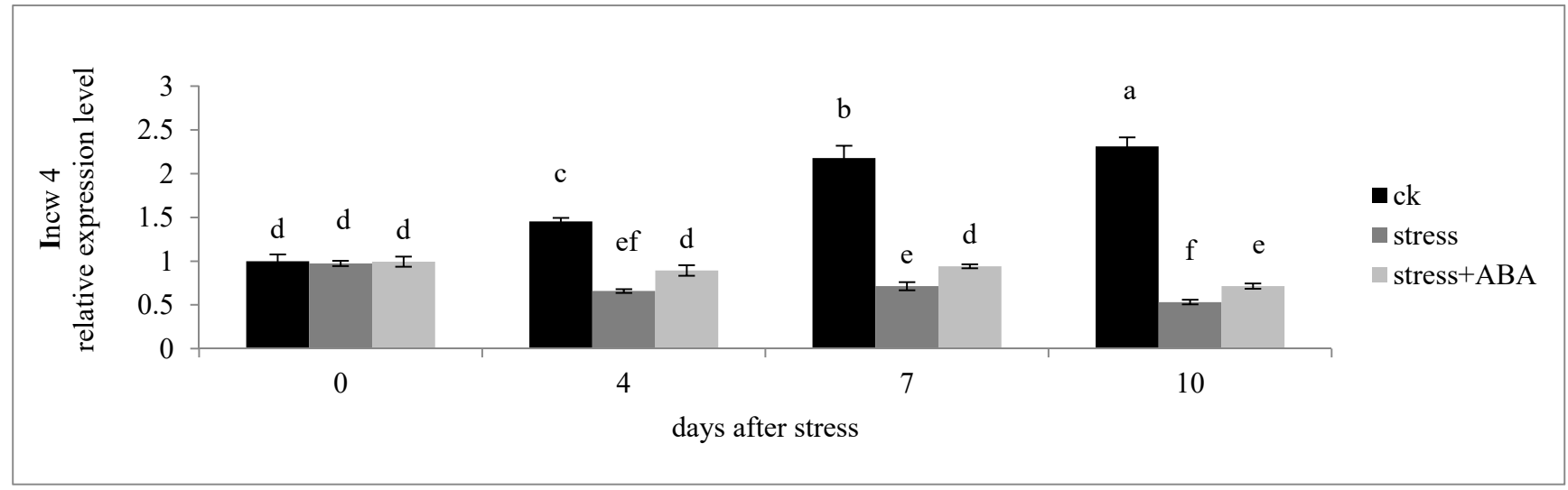

$(\mathbf{F})$

Figure 6. Effects of exogenous ABA application on the relative expression level of IVR1 (A), IVR 2 (B), Incw1 (C), Incw2 (D), Incw3 (E), and Incw4 (F) in ovaries of maize seedlings exposed to drought stress for 10 days. The data represent the means of independent measurements from five replicates. Standard deviation is indicated by vertical error bars. Values with the same lowercase letters on the bars are not significantly different at $p<0.05$.

The relative levels of Incw 1, 2, 3, and 4 observed in untreated plants increased gradually with treatment time and reached the highest value on the 10th day after treatment initiation. On the 10th day, the relative levels of Incw 2 were higher than those of Incw 1, 3, and 4. Under drought stress, the transcription levels of Incw 1, Incw 2, Incw 3, and Incw 4 decreased, while ABA application inhibited the decline of transcription levels, and had a significant effect on the transcription levels of Incw 2 and Incw 4. Further, on the 4th, 7th, and 10th days, the transcription level of Incw 1 was downregulated to a larger extent than that of Incw 2, Incw 3, and Incw 4 under drought stress. Lastly, the effect of ABA treatment on Incw 2 transcription was greater than the same effect on transcription of Incw 1, Incw 3, and Incw 4.

\subsection{Effects of Drought Stress and/or ABA Application on the Maize Yield Components}

There was no difference in the number of ears between drought stress and CK treatments on the 4th day after treatment initiation. However, on the 4th, 7 th, and 10th days, there were significant differences in bald tip length, grain number per ear, and 1000-grain weight, between drought stress and CK, and the number of kernels per ear and 1000-grain weight decreased significantly after 10 days of treatment (Table 3). The bald tip was the most serious problem and had the greatest impact on the final yield. If a water deficit occurs during the maize filling period, it will have a great impact on maize yield. In this study, the effect of 10 days of water stress on the final yield was the greatest. However, the application of ABA relieved the reduction of the yield index. Under drought treatment for 
4 and 7 days, the application of ABA significantly increased the number of grains per row and 1000-grain weight, but there was no significant increase on the 10th day.

Table 3. Effects of drought stress and/or ABA application on ear characters and yield components of maize kernels exposed to drought stress for 10 days.

\begin{tabular}{|c|c|c|c|c|c|c|c|c|c|}
\hline \multicolumn{2}{|c|}{ Treatment } & \multirow{2}{*}{$\begin{array}{c}\begin{array}{c}\text { Bald Tip } \\
\text { (cm) }\end{array} \\
1.0\end{array}$} & \multirow{2}{*}{$\begin{array}{c}\text { Compare } \\
\text { with } \\
\text { CK }(\%)\end{array}$} & \multirow{2}{*}{$\begin{array}{c}\begin{array}{c}\text { Row } \\
\text { Number } \\
\text { (Row) }\end{array} \\
18\end{array}$} & \multirow{2}{*}{$\begin{array}{c}\text { Compare } \\
\text { with } \\
\text { CK }(\%)\end{array}$} & \multirow{2}{*}{$\begin{array}{c}\begin{array}{c}\text { Grain } \\
\text { Number } \\
\text { Per Row } \\
\text { (Grain) }\end{array} \\
40\end{array}$} & \multirow{2}{*}{$\begin{array}{c}\text { Compare } \\
\text { with } \\
\text { CK (\%) }\end{array}$} & \multirow{2}{*}{$\begin{array}{c}1000 \text { Grain } \\
\text { Weight } \\
\text { (g) }\end{array}$} & \multirow{2}{*}{$\begin{array}{c}\text { Compare } \\
\text { with } \\
\text { CK (\%) }\end{array}$} \\
\hline \multirow{4}{*}{ 4th day } & CK & & & & & & & & \\
\hline & Stress & 3.0 & +200.0 & 18 & 0 & 31 & -22.5 & 369.8 & -14.8 \\
\hline & Stress + ABA & 2.2 & +120.0 & 18 & 0 & 37 & -7.5 & 390.2 & -10.1 \\
\hline & CK & 1.1 & & 18 & & 40 & & 402.0 & \\
\hline \multirow[t]{3}{*}{ 7th day } & stress & 4.5 & +309.1 & 14 & -22.2 & 25 & -37.5 & 337.8 & -16.0 \\
\hline & stress $+\mathrm{ABA}$ & 3.2 & +190.9 & 16 & -11.1 & 32 & -20 & 353.0 & -12.2 \\
\hline & CK & 1.2 & & 18 & & 42 & & 451.8 & \\
\hline \multirow[t]{2}{*}{ 10th day } & stress & 6.1 & +408.3 & 12 & -33.3 & 17 & -59.5 & 238.2 & -47.3 \\
\hline & stress + ABA & 5.2 & +333.3 & 14 & -22.2 & 23 & -50.0 & 292.6 & -35.2 \\
\hline
\end{tabular}

\section{Discussion}

The phytohormone abscisic acid (ABA) is known to regulate plant growth in many plant species including melon [40], potato [41], and wheat [42]. In this experiment, ABA pretreated plants were more tolerant to water deficit than untreated plants, as indicated by the sustained level of yield components. ABA effectively attenuated the negative effects of water deficit on maize yield components.

Water stress-induced sucrose breakdown was severely affected, leading to a shortage of starch synthesis materials and ultimately causing plant growth inhibition. Sucrose is hydrolyzed into fructose and glucose by INVs [43]. In turn, SS hydrolyzes sucrose into fructose and UDP-glucose, a prerequisite for starch synthesis [44]. In this study, the sucrose content in the grains increased under drought stress during the filling stage, but glucose and fructose contents did not. On the one hand, the increase in sucrose content in grains may be due to the increase in photosynthesis and the enhancement of carbon assimilation at the source end, while, on the other hand, the inhibition of sucrose breakdown at the sink end limits starch synthesis and accumulation. However, some studies have shown that leaf photosynthesis decreases and carbohydrate synthesis slow down under drought stress [45], whereby sucrose breakdown was slowed down. The decrease in SS activity and INV activity under drought stress observed here showed that the activities of enzymes related to carbon metabolism may partly explain the inhibition of carbon metabolism in the grain under drought stress.

Jiang et al. (2011) reported that sucrose synthase activity was positively correlated with crop yield [46]. The main function of sucrose synthase is not to catalyze the synthesis of sucrose, but to decompose sucrose into uridine diphosphate glucose (UDPG) and fructose, thus providing sugar groups for starch synthesis [20,47]. In this study, the activity of SS in maize grains increased rapidly during the early stages of drought stress. Then, SS activity decreased slowly over the duration of the water deficit (Figure 2), which may be a stress response to adapt to the stress. Previous studies have found that the activity of CIN is essential for the growth and development of Arabidopsis thaliana, while the activity of SS is sometimes very low or even not detected [15]. It is worth noting that for many plant species to establish a strong sink, SS activity is necessary and cannot be replaced by CIN activity [48]. Previous studies found that there was no significant linear relationship between SS activity and starch content, indicating that starch synthesis is regulated by a series of enzymes among which SS is not the only rate-limiting enzyme [49].

Sugars and INVs play a key role in crop reproductive development under drought conditions. Drought stress can affect carbon metabolism at all stages of plant growth and 
development, and reduce the activities of VIN and CWIN [50]. In young ovaries, in addition to the decrease in photoassimilate supply, the activity of INVs was also reduced, which in turn seriously reduced the utilization of endogenous Suc [50]. This is consistent with the results of our experiment and was evident as early as the 4th day from stress initiation (Figure 3). After continuous severe drought treatment, the concentration of Suc in the ovary was higher. The activities of VIN and CWIN can enhance the transformation of sucrose, increase the concentration gradient, promote the transfer of sucrose from source to sink, and accelerate carbon metabolism and increase sugar storage [51]. Importantly, the level of exosome-glucose in seeds, fruits, and other organs may need to be kept at optimum levels to maintain orderly development [52]. In this study, ABA treatment improved the activity of INVs under drought stress. Susan (1999) found that the miniature seed phenotype of the Incw2 deficient mutant could not be restored even under conditions of exogenous hexose application [53]. Similarly, another specific CWIN in tobacco was inhibited [54] and, even if glucose and fructose were supplied exogenously, pollen development could not be completely restored [55]. These studies suggest that CWIN may regulate the release of hexose through sugar signaling rather than just supplying nutrients. Molecular genetic studies have shown that CWIN can control cell division in offspring tissues, namely endosperm, and embryo. Therefore, it regulates seed development and even controls the rate and completeness of seed development [56].

The roles of CWIN and VIN in plants have been previously discussed in detail, and great progress has been made. However, there is much less information about the function of CIN, which is closely related to its structural instability and weak activity [57]. This is consistent with the results of the experiment reported herein. At the early stage of grain development, CIN activity was low. At present, it is still unclear how the activities of CWIN and VIN affect seed development, determine fruit setting rate and subsequent development, and how this important regulatory role is realized [58]. In the future, it will be necessary to further determine the precise cellular localization of these proteins and their respective inhibitors. Further, it will be necessary to expand our knowledge of metabolite profiles in the early stages of seed and fruit development.

Previous studies have shown that invertase activity and transcript expression are abnormal in higher plants under stress. In this experiment, the changes in the relative abundance of IVR2 and Incw2 mRNA differed significantly; consistent with the changes observed in soluble and insoluble invertase activities, respectively. These data show that the abundance of transcripts is positively correlated with the activities of the two invertases and that both play an important regulatory role. In the process of Suc hydrolysis and assimilate transfer to the developing endosperm, Incw2 cell-wall binding invertase not only participates in the reaction but also plays an important regulatory role [59]. It has been reported that the expression of Incw 1 is almost the same during early seed development but it is significantly different at the later stage of seed development [60]. However, in this experiment, the expression of Incw 1 was significantly different under water stress at the early stage of grain development. Before and after pollination, water deficit results in changes in the expression of many genes [61]. Chourey et al. [53] found variation in Incw2 and IVR1 gene expression in wheat during a water shortage period and concluded that these two genes were closely related to stress physiology [55]. This is consistent with these experimental results. Therefore, they inferred that these two genes are related to stress resistance and proposed that the variability in their expression can be used to improve crop drought resistance. During pollination and grain filling water deficit leads to changes in the expression of many genes [61]. There is evidence that ABA can regulate plant development, including changes at the molecular level [62]. This is consistent with the observation that exogenous ABA regulates the expression of the invertase gene. Numerous studies show that water deficit plays an important role in maize grain formation [63]. Whether it is possible to enhance enzyme activity and carbon metabolism by changing gene expression according to this regulatory effect warrants further study. 
Drought stress shortened ear length and number of grains per ear. Previous studies on the changes in maize yield components under drought stress have rendered different results [64-66]. Here, our experiment showed that the ear development of maize was poor when drought stress occurred in the early filling stage. Bald tip, row number, grain number per row, and 1000-grain weight changed with the duration of drought stress treatment. The more prolonged the stress, the more severe the reduction in yield index, consistent with the changes observed in SS and INV activities during stress. Thus, enzyme activity was positively correlated with yield. Finally, the exogenous application of ABA at least partially restored maize ear development.

\section{Conclusions}

The results reported herein showed that, under drought stress, ABA promoted the breakdown of Suc to Glu and Fru by increasing SS and INV activities. At the same time, ABA-induced the transcriptional up-regulation of INVs, thereby helping to sustain the yield index. The changes in the expression levels of IVR1, IVR2, and Incw2 were consistent with the changes in the levels of the corresponding enzyme transcripts and activities. Therefore, the ABA-mediated increase in SS and INV activities enhanced normal carbon metabolism, alleviated growth inhibition, and enhanced plant tolerance to drought stress.

Author Contributions: Conceptualization, M.L.; data curation, Z.J.; formal analysis, Z.J. and L.P.; funding acquisition, M.L.; investigation, L.P.; methodology, C.L. and M.L.; project administration, M.L.; resources, M.L.; supervision, C.L. and M.L.; validation, S.W., H.Z. (Hengguang Zhu), and Z.Y.; writing-original draft, Z.J., Y.T.; writing—review and editing, Z.J., H.Z. (Hanyu Zhu), D.G., and M.L. All authors have read and agreed to the published version of the manuscript.

Funding: We are grateful for the support from the grants from China Postdoctoral Science Foundation Project (2018M631905) and the Innovation project of ministry of science and technology of China (2017YFD0300506-2).

Data Availability Statement: Not applicable.

Acknowledgments: We are grateful for the high efficiency and valuable comments by the editor and reviewers who thus contributed significantly to the improvement of our manuscript.

Conflicts of Interest: The authors declare no conflict of interest.

\section{References}

1. Naveed, M.; Mitter, B.; Reichenauer, T.G.; Wieczorek, K.; Sessitsch, A. Increased drought stress resilience of maize through endophytic colonization by Burkholderia phytofirmans, PsJN and enterobacter sp. FD17. Environ. Exp. Bot. 2014, 97, 30-39. [CrossRef]

2. Nuccio, M.L.; Wu, J.; Mowers, R.; Zhou, H.P.; Meghji, M.; Primavesi, L.F.; Paul, M.J.; Chen, X.; Gao, Y.; Haque, E.; et al. Expression of trehalose-6-phosphate phosphatase in maize ears improves yield in non-stressed and drought conditions. Nat. Biotechnol. 2015, 33, 862-869. [CrossRef]

3. Zhao, J.; Yang, X.G.; Sun, S. Constraints on maize yield and yield stability in the main cropping regions in China. Eur. J. Agron. 2018, 99, 106-115. [CrossRef]

4. Li, Y.B.; Tao, H.B.; Zhang, B.C.; Huang, S.B.; Wang, P. Timing of water deficit limits maize kernel setting in association with changes in the source-flow-sink relationship. Front Plant Sci. 2018, 9, 1326. [CrossRef]

5. Chen, T.; Zhang, H.; Zeng, R.; Wang, X.; Huang, L.; Wang, L.; Wang, X.; Zhang, L. Shade effects on peanut yield associate with physiological and expressional regulation on photosynthesis and sucrose metabolism. Inter. J. Mol. Sci. 2020, 21, 5284. [CrossRef]

6. Lu, M.Z.; Snyder, R.; Grant, J.; Tegeder, M. Manipulation of sucrose phloem and embryo loading affects pea leaf metabolism, carbon and nitrogen partitioning to sinks as well as seed storage pools. Plant J. 2020, 101, 217-236. [CrossRef] [PubMed]

7. Braun, D.M.; Wang, L.; Ruan, Y.L. Understanding and manipulating sucrose phloem loading, unloading, metabolism, and signalling to enhance crop yield and food security. J. Exp. Bot. 2014, 65, 1713-1735. [CrossRef] [PubMed]

8. Luo, T.; Shuai, L.; Liao, L.; Li, J.; Duan, Z.; Guo, X.; Xue, X.; Han, D.; Wu, Z. Soluble Acid Invertases Act as Key Factors Influencing the Sucrose/Hexose Ratio and Sugar Receding in Longan (Dimocarpus longan L.) Pulp. J. agric. Food Chem. 2019, 67, 352-363. [CrossRef] [PubMed]

9. Belhassine, F.; Martinez, S.; Bluy, S.; Fumey, D.; Kelner, J.J.; Costes, E.; Pallas, B. Fruit growth, photosynthesis and starch accumulation are differentially affected by local variation in source/sink ratios. Acta Hortic. 2020, 1281, 455-462. [CrossRef] 
10. Antonietta, M.; Fanello, D.D.; Acciaresi, H.A.; Guiamet, J.J. Senescence and yield responses to plant density in stay green and earlier-senescing maize hybrids from Argentina. Field Crops Res. 2014, 155, 111-119. [CrossRef]

11. Khan, N.A.; Murayama, S.; Ishimine, Y.; Tsuzuki, E.; Nakamura, I. Physio-morphological Studies of F1 Hybrids in Rice (Oryza sativa L.): Photosynthetic ability and yield. Plant Prod. Sci. 1998, 1, 233-239. [CrossRef]

12. Milne, R.J.; Perroux, J.M.; Rae, A.L.; Reinders, A.; Ward, J.M.; Offler, C.E.; Patrick, J.W.; Grof, C.P.L. Sucrose transporter localization and function in phloem loading and unloading. Plant Physiol. 2016, 173, 1330-1341. [CrossRef]

13. Ghassemi-Golezani, K.; Raei, N.; Raei, Y. Effects of water deficit and nitrogen levels on grain yield and oil and protein contents of maize. Azarian J. Agric. 2015, 2, 46-50.

14. Wu, X.; Cai, K.; Zhang, G.; Zeng, F. Metabolite profiling of barley grains subjected to water stress: To explain the genotypic difference in drought-induced impacts on malting quality. Front. Plant Sci. 2017, 8, 1547. [CrossRef]

15. Barratt, D.H.P.; Derbyshire, P.; Findlay, K.; Pike, M.; Wellner, N.; Lunn, J.; Feil, R.; Simpson, C.; Maule, A.J.; Smith, A.M. Normal growth of Arabidopsis requires cytosolic invertase but not sucrose synthase. Proc. Natl. Acad. Sci. 2009, 106, 13124-13129. [CrossRef] [PubMed]

16. Xu, S.M.; Brill, E.; Llewellyn, D.J.; Furbank, R.T.; Ruan, Y.-L. Overexpression of a potato sucrose synthase gene in cotton accelerates leaf expansion, reduces seed abortion, and enhances fiber production. Mol. Plant. 2012, 5, 430-441. [CrossRef] [PubMed]

17. Ranwala, A.P.; Baird, W.V.; Miller, W.B. Organ-specific localization and molecular properties of three soluble invertases from Lilium longiflorum flower beds. Physiol. Plant. 1998, 103, 551-559. [CrossRef]

18. Bieniawska, Z.; Barratt, D.H.P.; Garlick, A.P.; Thole, V.; Kruger, N.J.; Martin, C.; Zrenner, R.; Smith, A.M. Analysis of the sucrose synthase gene family in Arabidopsis. Plant J. 2007, 49, 810-2827. [CrossRef]

19. Chourey, P.S.; Taliercio, E.W.; Carlson, S.J.; Ruan, Y.-L. Genetic evidence that the two isozymes of sucrose synthase present in developing maize endosperm are critical, one for cell wall integrity and the other for starch biosynthesis. Mol. Gen. Genet. 1998, 259, 88-96. [CrossRef]

20. Wang, F.; Sanz, A.; Brenner, M.L.; Smith, A. Sucrose synthase, starch accumulation, and tomato fruit sink strength. Plant Physiol. 1993, 101, 321-327. [CrossRef]

21. Zrenner, R.; Salanoubat, M.; Willmitzer, L.; Sonnewald, U. Evidence of the crucial role of sucrose synthase for sink strength using transgenic potato plants (Solanum tuberosum L.). Plant J. 2010, 7, 97-107. [CrossRef] [PubMed]

22. Travaglia, C.; Cohen, A.C.; Reinoso, H.; Castillo, C.; Bottini, R. Exogenous abscisic acid increases carbohydrate accumulation and redistribution to the grains in wheat grown under field conditions of soil water restriction. J. Plant Growth Regul. 2007, 26, 285-289. [CrossRef]

23. Bray, E.A. Abscisic acid regulation of gene expression during water-deficit stress in the era of the Arabidopsis genome. Plant Cell Environ. 2010, 25, 153-161. [CrossRef]

24. Souza, T.C.; Magalhães, P.C.; Castro, E.M.; Albuquerque, P.E.P.; Marabesi, M.A. The influence of ABA on water relation, photosynthesis parameters, and chlorophyll fluorescence under drought conditions in two maize hybrids with contrasting drought resistance. Acta Physiol. Plant. 2013, 35, 515-527. [CrossRef]

25. Nieves, N.; Martínez, M.E.; Castillo, R.; Blanco, M.A. Effect of abscisic acid and jasmonic acid on partial desiccation of encapsulated somatic embryos of sugarcane. Plant Cell Tiss. Org. Cult. 2001, 65, 15-21. [CrossRef]

26. Prabu, G.; Kawar, P.G.; Pagariya, M.C.; Prassad, D.T. Identification of water deficit stress upregulated genes in sugarcane. Plant Mol. Biol. Rep. 2010, 29, 291-304. [CrossRef]

27. Mittal, A.; Gampala, S.S.L.; Ritchie, G.L.; Payton, P.; Burke, J.J.; Rock, C.D. Related to ABA-Insensitive3 (ABI3)/Viviparous1 and AtABI5 transcription factor coexpression in cotton enhances drought stress adaptation. Plant Biotechnol J. 2014, 12, 578-589. [CrossRef]

28. Liu, F. Loss of pod set caused by drought stress is associated with water status and ABA content of reproductive structures in soybean. Funct. Plant Biol. 2003, 30, 271-280. [CrossRef]

29. Lim, C.W.; Yang, S.H.; Shin, K.H.; Lee, S.C.; Kim, S.H. The AtLRK10L1.2, Arabidopsis ortholog of wheat LRK10, is involved in ABA-mediated signaling and drought resistance. Plant Cell Rep. 2015, 34, 447-455. [CrossRef]

30. Liu, H.; Searle, I.R.; Mather, D.E.; Able, A.; Able, J. Morphological, physiological and yield responses of durum wheat to pre-anthesis water deficit stress are genotype-dependent. Crop Past. Sci. 2015, 66, 1024-1038. [CrossRef]

31. Souza, T.C.; Magalhães, P.C.; Castro, E.M.; Carneiro, N.P.; Padiha, F.A.; Gomes, C.C. ABA application to maize hybrids contrasting for drought tolerance: Changes in water parameters and in antioxidant enzyme activity. Plant Growth Regul. 2014, 73, 205-217. [CrossRef]

32. Marx, D.H.; Hatch, A.B.; Mendicino, J.F. High soil fertility decreases sucrose content and susceptibility of loblolly pine roots to ectomycorrhizal infection by Pisolithus tinctorius. Canadian J. Bot. 1977, 55, 1569-1574. [CrossRef]

33. Abdellatif, B.; Jun, L.; Miroslav, O.; Ezquer, I.; Muñoz, F.I.; Baroja-Fernández, E.; Romero, J.M.; Almagro, G.; Montero, M.; Hidalgo, M.; et al. Arabidopsis thaliana mutants lacking ADP-glucose pyrophosphorylase accumulate starch and wild-type ADP-glucose content: Further evidence for the occurrence of important sources, other than ADP-glucose pyrophosphorylase, of ADP-glucose linked to leaf starch biosynthesis. J Plant Cell Physiol. 2011, 7, 1162-1176.

34. Suzuki, Y.; Odanaka, S.; Kanayama, Y. Fructose content and fructose-related enzyme activity during the fruit development of apple and japanese pear. J. Jpn. Soc. Hortic. Sci. 2001, 70, 16-20. [CrossRef] 
35. Douglas, C.D.; Tsung, M.K.; Frederick, C.F. Enzymes of sucrose and hexose metabolism in development of kernels of two inbreds of maize. Plant Physiol. 1988, 86, 1013-1019.

36. Tsai-Mei, O.L.; Lloyd, S.T. Effect of increased temperature in apical regions of maize ears on starch-synthesis enzymes and accumulation of sugars and starch 1. Plant Physiol. 1985, 79, 852-855.

37. Yong-Jian, S.; Yuan-Yuan, S.; Kai, L. Effects of water-nitrogen interaction on rice senescence and material transport and yield during grain filling. Plant Nutr. Fert. Sci. 2009, 15, 1339-1349.

38. Liu, Y.J.; Yuan, Y.; Liu, Y.Y.; Liu, Y.; Fu, J.J.; Zheng, J.; Wang, G.Y. Gene families of maize glutathione-ascorbate redox cycle respond differently to abiotic stresses. J.Plant Physiol. 2012, 169, 183-192. [CrossRef] [PubMed]

39. Tristan, C.; Shahani, N.; Sedlak, T.W.; Sawa, A. The diverse functions of GAPDH: Views from different subcellular compartments. J. Cell. Signal. 2011, 23, 317-323. [CrossRef]

40. Zhang, M.; Yuan, B.; Leng, P. Cloning of 9-cis-epoxycarotenoid dioxygenase (NCED) gene and the role of ABA on fruit ripening. Plant Signal. Behav. 2009, 4, 460-463. [CrossRef]

41. Li, C.N.; Manoj, K.S.; Nong, Q.; Li, Y.R. Mechanism of tolerance to drought in sugarcane plant enhanced by foliage dressing of abscisic acid under water stress. Acta Agron. Sin. 2010, 36, 863-870. [CrossRef]

42. Kaur, S.; Gupta, A.K.; Zhawar, V.K. ABA-dependent sucrose regulation of antioxidant metabolism in wheat cultivars varying in ABA-sensitivity. Biologia 2015, 70, 165-173. [CrossRef]

43. Farrokhi, Z.; Alizadeh, H.; Alizadeh, H. Developmental patterns of enzyme activity, gene expression, and sugar content in sucrose metabolism of two broomrape species. Plant Physiol. Biochem. 2019, 142, 8-14. [CrossRef] [PubMed]

44. Gessler, A. Sucrose synthase - an enzyme with a central role in the source-sink coordination and carbon flow in trees. New Phytol. 2021, 229, 186-198. [CrossRef]

45. Irigoyen, J.J.; Emerich, D.W.; Sánchez-Díaz, M. Alfalfa leaf senescence induced by drought stress: Photosynthesis, hydrogen peroxide metabolism, lipid peroxidation and ethylene evolution. Physiol. Plant. 1992, 84, 67-72. [CrossRef]

46. Jiang, Q.; Hou, J.; Hao, C.; Wang, L.; Ge, H.; Dong, Y.; Zhang, X. The wheat (T. aestivum) sucrose synthase 2 gene (TaSus2) active in endosperm development is associated with yield traits. Funct Integr. Genom. 2011, 11, 49-61. [CrossRef]

47. Chengappa, S.; Guilleroux, M.; Phillips, W.; Shields, R. Transgenic tomato plants with decreased sucrose synthase are unaltered in starch and sugar accumulation in the fruit. Plant Mol. Biol. 1999, 40, 213-221. [CrossRef]

48. Schaffer, M.A.A. Sucrose phosphate synthase, sucrose synthase, and invertase activities in developing fruit of Lycopersicon esculentum, Mill and the sucrose accumulating Lycopersicon hirsutum Humb and Bonpl. Plant Physiol. 1991, 95, 623-627.

49. Counce, P.A.; Gravois, K.A. Sucrose synthase activity as a potential indicator of high rice grain yield. Crop Sci. 2013, 46, 1501-1507. [CrossRef]

50. Andersen, M.N. Soluble invertase expression is an early target of drought stress during the critical, abortion-sensitive phase of young ovary development in maize. Plant Physiol. 2002, 130, 591-604. [CrossRef]

51. Verma, I.; Roopendra, K.; Sharma, A.; Chndra, A.; Kamal, A. Expression analysis of genes associated with sucrose accumulation and its effect on source-sink relationship in high sucrose accumulating early maturing sugarcane variety. Physiol. Mol. Biol. Plants. 2019, 25, 207-220. [CrossRef] [PubMed]

52. Hu, M.; Shi, Z.; Zhang, Z.; Zhang, Y. Effects of exogenous glucose on seed germination and antioxidant capacity in wheat seedlings under salt stress. J. Plant Growth Regul. 2012, 68, 177-188. [CrossRef]

53. Chourey, C.P.S. A re-evaluation of the relative roles of two invertases, INCW2 and IVR1, in developing maize kernels and other tissues. Plant Physiol. 1999, 121, 1025-1035.

54. Hu, Y.P.; Liu, J.; Zhou, Y.; Xia, W.R.; Li, R.M.; Duan, R.J.; Fu, S.P.; Hu, X.W.; Guo, J.C.; Hu, Y.P. Cloning of MeCWINV3 Promoter from Cassava and Transient Expression Analysis in Tobacco. Appl. Mech. Mat. 2014, 522-524, 326-331. [CrossRef]

55. Hirche, J.; García, J.M.; Sabentheiner, E.; Grobkinsky, D.K.; Roitsch, T. Differential effects of carbohydrates on Arabidopsis pollen germination. Plant Cell Physiol. 2017, 58, 691-701. [CrossRef]

56. Jameson, P.E.; Dhandapani, P.; Novak, O.; Song, J. Cytokinins and expression of SWEET, SUT, CWINV and AAP Genes Increase as pea seeds germinate. Inter. J. Mol. Sci. 2016, 17, 2013. [CrossRef] [PubMed]

57. Shao, X. Differences in sucrose metabolism in peach fruit stored at chilling stress versus nonchilling stress temperatures. Hort. Sci. 2015, 50, 1542-1548.

58. Ruan, Y.L.; Jin, Y.; Yang, Y.J.; Yang, Y.J.; Li, G.J.; Boyer, J.S. Sugar input, metabolism, and signaling mediated by invertase: Roles in development, yield potential, and response to drought and heat. Mol. Plant 2010, 3, 942-955. [CrossRef]

59. Carlson, S.J.; Shanker, S.; Chourey, P.S. A point mutation at the Miniature1 seed locus reduces levels of the encoded protein, but not its mRNA, in maize. Mol. Gen. Genet. 2000, 263, 367-373. [CrossRef]

60. Chourey, P.S.; Jain, M.; Li, Q.B.; Carlson, S.J. Genetic control of cell wall invertase in developing endosperm of maize. Planta 2006, 223, 159-167. [CrossRef]

61. Zinselmeier, C.; Sun, Y.; Helentjaris, T.; Beatty, M. The use of gene expression profiling to dissect the stress sensitivity of reproductive development in maize. Field Crops Res. 2002, 75, 111-121. [CrossRef]

62. Barbosa, E.G.G.; Leite, J.P.; Rockenbach, S.R.; Marinho, J.P.; Correa, J.F.; Fuganti, R.; Boucas, J.R.; Neumaier, N.; Marcelino, F.C.; De Oliveira, M.C.N.; et al. Overexpression of the ABA-dependent AREB1 transcription factor from Arabidopsis thaliana improves soybean tolerance to water deficit. Plant Mol. Biol. Rep. 2013, 31, 719-730. [CrossRef] 
63. Bazrafshan, A.; Shorafa, M.; Mohammadi, M.; Zolfaghari, A.A.; van de Craats, D.; van der Zee, S.E.A.T.M. Comparison of the individual salinity and water deficit stress using water use, yield, and plant parameters in maize. Environ. Monit. Assess. 2020, 192, 1-14. [CrossRef] [PubMed]

64. Wang, B.; Liu, C.; Zhang, D.; He, C.; Zhang, J.; Li, Z. Effects of maize organ-specific drought stress response on yields from transcriptome analysis. BMC Plant Biol. 2019, 19, 335. [CrossRef] [PubMed]

65. Eliaspour, S.; Sharifi, R.S.; Shirkhani, A.; Farzaneh, S. Effects of biofertilizers and iron nano-oxide on maize yield and physiological properties under optimal irrigation and drought stress conditions. Food Sci. Nutr. 2020, 11, 5985-5998. [CrossRef] [PubMed]

66. Rezende, W.S.; Beyene, Y.; Mugo, S.; Ndou, E.; Gowda, M.; Sserumaga, J.P.; Asea, G.; Ngolinda, I.; Jumbo, M.; Oikeh, S.O.; et al. Performance and yield stability of maize hybrids in stress-prone environments in eastern Africa. Crop J. 2020, 8, 107-118. [CrossRef] 